\title{
Új albanerpetontida (Allocaudata: Albanerpetontidae) leletek az iharkúti késő-kréta szárazföldi ősgerinces lelőhelyről
}

\author{
SZENTESI ZOLTÁN \\ Magyar Természettudományi Múzeum, Öslénytani és Földtani Tár, \\ 1083 Budapest, Ludovika tér 2-6., Magyarország \\ E-mail: szentesi.zoltan@nhmus.hu
}

\begin{abstract}
Összefoglalás - Az iharkúti késő-kréta (santoni) ősgerinces lelőhelyen gyakoriak az Albanerpetontidae (Allocaudata) családba sorolható szalamandraszerü kétéltüek izolált, töredékes leletei, melyek a diagnosztikus frontale hiánya miatt nem sorolhatóak be család szintnél alacsonyabb rendszertani egységbe. A leletek azonban két csoportra oszthatóak méretük alapján: egy normálméretűre és egy óriásra, mely adatok alapján a lelőhelyről előkerült albanerpetontida leletek legalább két taxont képviselnek. Az itt leírt két bal dentale megerősíti ezt a feltevést, és egyben azt sugallja, hogy az óriásméretủ albanerpetontidák nem voltak nagyon ritkák az egykori területen a santoni időszakban.
\end{abstract}

Kulcsszavak - Albanerpetontidae, Iharkút, kréta, paleoökológia, őskörnyezet

\section{BEVEZETÉS}

$\mathrm{Az}$ Albanerpetontidae család tagjai szalamandraszerủ modern kétéltủek (Lissamphia), melyek szorosan kötődnek a szalamandrákhoz és a békákhoz, és esetleg a lábatlan kétéltüekhez is (Fox \& NAYLOR 1982, MCGowan \& EvaNs 1995, Gardner 2001, Gardner \& BöHme 2008). Az albanerpetontidák többnyire izolált, sokkal ritkábban részleges vagy teljes csontváz leletek alapján ismertek Európából, Észak-Amerika nyugati részéről, Észak-Afrikából, KözépÁzsiából és Japánból (GARDNER \& BöHME 2008, MATSUMOTO \& EVANS 2018). A mára már kihalt család Európában a középső-jurától (SEIFFERT 1969, EvANS \& Milner 1994, Evans \& WALDMAN 1996) a pliocén végéig (MN16A) volt jelen (Delfino \& SAla 2007, Szentesi et al. 2015). Az Albanerpetontidae családba jelenleg öt nem és 13 érvényes faj tartozik (pl. GARDNER \& BöHME 2008, Matsumoto \& Evans 2018). 
Az albanerpetontidák a mai Magyarország területén az iharkúti későkréta (santoni) ősgerinces lelőhelyről ismertek (SZENTESI 2006a, 2006b, SZENTESI 2012, SZENTESI et al. 2013, GARDNER et al. 2009), valamint a Villányihegységből, a pliocén korú Csarnóta 2 lelőhelyről izolált, de kiváló megtartású leletek alapján egy új faj lett leírva Albanerpeton pannonicum néven (VENCZEL \& GARDNER 2005), mely faj jelenléte a Csarnóta 3 lelőhelyen (felső-pliocén, MN16A) szintén igazolást nyert (SzENTEsi et al. 2015).

A késő-kréta iharkúti ősgerinces lelőhelyről a kétéltűek kizárólag izolált, többnyire töredékes csontleletek alapján ismertek. A békaleletek között több diagnosztikus csontlelet (elsősorban iliumok) is előkerült, melyek alapján két új békafaj is leírásra került ezek alapján (SZENTESI \& VENCZEL 2010, SZENTESI \& VENCZEL 2012) Az albanerpetontida leletek szintén izoláltak (1. tábla), rossz megtartásúak, és mindmáig hiányoznak a taxonómiai besoroláshoz nélkülözhetetlen diagnosztikus csontok. Az itt bemutatott leletek sem oldják meg a taxonómiai problémákat, de kiegészítik az eddig szerzett ismereteket.

1. tábla. A késő-kréta (santoni) iharkúti ősgerinces lelőhelyről előkerült Albanerpetontidae leletek

\begin{tabular}{|c|c|c|c|c|}
\hline leltári szám & csont & méret & lelőhely & említve \\
\hline \multirow[t]{2}{*}{ V 2008.22.1. } & bal premaxilla & normál & Szál-7 & Szentesi 2012 \\
\hline & & & & Szentesi et al. 2013 \\
\hline V 2008.23.1. & jobb premaxilla & & & \\
\hline V 2008.24.1. & bal premaxilla & & & \\
\hline \multirow[t]{4}{*}{ V 2008.25.1. } & bal dentale & & Szál-6 & Makádi et al. 2006 \\
\hline & & & & Szentesi et al. 2006 \\
\hline & & & & Szentesi 2012 \\
\hline & & & & Szentesi et al. 2013 \\
\hline V 2008.26.1. & jobb dentale & & Szál-7 & \\
\hline V 2008.27.1. & 25 dentale-töredék & & Szál-6 & Szentesi 2012 \\
\hline \multirow[t]{2}{*}{ V 2008.28.1. } & maxilla-töredék & & & Szentesi 2012 \\
\hline & & & & Szentesi et al. 2013 \\
\hline \multirow[t]{2}{*}{ V 2008.29.1. } & dentale-töredék & óriás & & Szentesi 2012 \\
\hline & & & & Szentesi et al. 2013 \\
\hline
\end{tabular}




\begin{tabular}{|c|c|c|c|c|}
\hline leltári szám & csont & méret & lelöhely & említve \\
\hline V 2009.1.1. & jobb premaxilla & normál & Szál-7 & Szentesi et al. 2013 \\
\hline V 2009.2.1. & jobb dentale & & Szál-6 & Szentesi 2012 \\
\hline V 2009.3.1. & jobb dentale & & & \\
\hline V 2009.4.1. & jobb dentale & & & nem publikált \\
\hline V 2009.5.1. & dentale-töredék & & & Szentesi 2012 \\
\hline V 2009.6.1. & jobb dentale & & & \\
\hline V 2009.7.1. & dentale-töredék & & & \\
\hline \multirow[t]{2}{*}{ V 2009.8.1. } & bal dentale & & & Szentesi 2012 \\
\hline & & & & Szentesi et al. 2013 \\
\hline V 2009.9.1. & bal dentale & & & \\
\hline V 2009.10.1. & fogak & óriás & & \\
\hline V 2009.11.1. & dentale-töredék & normál & Szál-7 & Szentesi 2012 \\
\hline V 2009.12.1. & dentale-töredék & & & \\
\hline V 2009.13.1. & dentale-töredék & & & \\
\hline V 2009.14.1. & jobb dentale & & & \\
\hline V 2009.15.1. & dentale-töredék & & & \\
\hline V 2009.16.1. & jobb dentale & & & \\
\hline V 2009.17.1. & dentale-töredék & & & \\
\hline V 2009.18.1. & jobb dentale & & & \\
\hline V 2009.19.1. & dentale-töredék & & & \\
\hline V 2009.20.1. & dentale-töredék & & & \\
\hline V 2009.21.1. & dentale-töredék & & & \\
\hline \multirow[t]{2}{*}{ V 2009.26.1. } & bal dentale & & Szál-6 & Szentesi 2012 \\
\hline & & & & Szentesi et al. 2013 \\
\hline V 2009.28.1. & dentale-töredék & & Szál-8 & \\
\hline V 2009.29.1. & jobb maxilla & & & \\
\hline
\end{tabular}




\begin{tabular}{|c|c|c|c|c|}
\hline leltári szám & csont & méret & lelőhely & említve \\
\hline V 2009.30.1. & jobb maxilla & normál & Szál-8 & nem publikált \\
\hline V 2009.31.1. & jobb maxilla & & & \\
\hline \multirow[t]{2}{*}{ V 2009.32.1. } & jobb dentale & & Szál-6 & Szentesi 2012 \\
\hline & & & & Szentesi et al. 2013 \\
\hline V 2009.36.1. & bal premaxilla & & Szál-8 & nem publikált \\
\hline V 2009.37.1. & bal dentale & & & Szentesi 2012 \\
\hline V 2010.285.1. & bal maxilla & & & nem publikált \\
\hline V 2010.286.1. & bal dentale & & Szál-7 & Szentesi 2012 \\
\hline \multirow[t]{2}{*}{ V 2010.287.1. } & bal dentale & & & Szentesi 2012 \\
\hline & & & & Szentesi et al. 2013 \\
\hline V 2010.288.1. & jobb premaxilla & & Szál-8 & Szentesi et al. 2013 \\
\hline VER 2015.134.1. & bal dentale & óriás & Szál-6 & jelen munkában \\
\hline VER 2015.134.2. & bal dentale & óriás & & \\
\hline VER 2015.134.3. & jobb dentale & normál & & nem publikált \\
\hline VER 2015.134.4. & bal dentale & & & \\
\hline VER 2015.134.5. & fogak & & & \\
\hline VER 2015.134.6. & jobb dentale & & & nem publikált \\
\hline VER 2015.134.7. & jobb dentale & & & \\
\hline VER 2015.134.8. & bal dentale & & & \\
\hline VER 2015.134.9. & dentale-töredék & & & nem publikált \\
\hline VER 2015.134.10. & fogak & & & \\
\hline VER 2015.134.11. & bal dentale & & & \\
\hline VER 2015.134.12. & jobb dentale & & & \\
\hline VER 2015.134.13. & frontale-töredék & & & jelen munkában \\
\hline VER 2015.134.14. & dentale-töredék & & & nem publikált \\
\hline VER 2015.134.15. & bal dentale & & & \\
\hline
\end{tabular}




\begin{tabular}{|c|c|c|c|c|}
\hline leltári szám & csont & méret & lelőhely & említve \\
\hline VER 2015.134.16. & bal dentale & normál & Szál-6 & nem publikált \\
\hline VER 2015.134.17. & bal dentale & & & \\
\hline VER 2015.142.1. & ?frontale-töredék & & Szál-8 & \\
\hline VER 2015.142.2. & maxilla-töredék & & Szál-6 & nem publikált \\
\hline VER 2015.155.1. & jobb dentale & & & \\
\hline VER 2015.155.2. & jobb dentale & & & \\
\hline VER 2015.155.3. & bal dentale & & & \\
\hline VER 2015.155.4. & jobb dentale & & & \\
\hline VER 2015.155.5. & bal dentale & & & \\
\hline VER 2015.155.6. & dentale-töredék & & & \\
\hline VER 2015.155.7. & bal dentale & & & \\
\hline VER 2015.155.8. & dentale-töredék & & & \\
\hline VER 2015.155.9. & dentale-töredék & & & \\
\hline VER 2015.155.10. & bal dentale & & & \\
\hline VER 2015.155.11. & bal dentale & & & \\
\hline VER 2015.155.12. & dentale-töredék & & & \\
\hline VER 2015.155.13. & dentale-töredék & & & \\
\hline VER 2015.155.14. & jobb dentale & & Szál-8 & \\
\hline VER 2015.155.15. & bal dentale & & & \\
\hline VER 2015.155.16. & bal dentale & & & \\
\hline VER 2015.155.17. & bal dentale & & & \\
\hline VER 2015.155.18. & bal dentale & & & \\
\hline VER 2015.155.19. & bal dentale & & & \\
\hline VER 2015.155.20. & fogak & & & \\
\hline VER 2015.155.21. & dentale-töredék & & & \\
\hline VER 2015.155.22. & dentale-töredék & & & \\
\hline
\end{tabular}




\begin{tabular}{|c|c|c|c|c|}
\hline leltári szám & csont & méret & lelöhely & említve \\
\hline VER 2015.155.23. & jobb dentale & normál & Szál-6 & nem publikált \\
\hline VER 2015.155.24. & jobb dentale & & Szál-7 & \\
\hline VER 2015.155.25. & jobb dentale & & & \\
\hline VER 2015.155.26. & bal dentale & & & \\
\hline VER 2015.155.27. & dentale-töredék & & Szál-6 & \\
\hline VER 2015.155.28. & bal dentale & & & \\
\hline VER 2015.155.29. & maxilla-töredék & & & \\
\hline VER 2015.155.30. & bal premaxilla & & & \\
\hline VER 2015.155.31. & jobb dentale & & Szál-8 & \\
\hline VER 2015.155.32. & dentale-töredék & & Szál-6 & \\
\hline VER 2015.155.33. & dentale-töredék & & & \\
\hline VER 2015.155.34. & jobb dentale & & & \\
\hline VER 2015.155.35. & jobb dentale & & & \\
\hline VER 2015.155.36 & bal dentale & & & \\
\hline VER 2015.155.37. & jobb dentale & & & \\
\hline VER 2015.155.38. & maxilla-töredék & & & \\
\hline VER 2015.155.39. & jobb dentale & & & \\
\hline VER 2015.155.40. & jobb maxilla & & & \\
\hline VER 2015.155.41. & maxilla-töredék & & & \\
\hline VER 2015.155.42. & fogak & & & \\
\hline VER 2015.155.43. & maxilla-töredék & & & \\
\hline VER 2015.155.44. & fogak & & & \\
\hline VER 2015.155.45. & fogak & & & \\
\hline VER 2015.155.46. & jobb dentale & & & \\
\hline VER 2015.155.47. & dentale-töredék & & & \\
\hline VER 2015.155.48. & maxilla-töredék & & & \\
\hline
\end{tabular}




\begin{tabular}{lllll}
\hline leltári szám & csont & méret & lelöhely & említve \\
\hline VER 2015.155.49. & bal dentale & normál & Szál-6 & nem publikált \\
VER 2015.155.50. & bal dentale & & & \\
VER 2015.155.51. & dentale-töredék & & \\
VER 2015.155.52. & bal dentale & & \\
VER 2015.155.53. & bal dentale & \\
VER 2015.155.54. & bal dentale & & \\
VER 2015.155.55. & bal dentale & \\
VER 2016.1287. & dentale-töredék & \\
VER 2016.2845. & 2 jobb dentale & \\
\hline
\end{tabular}

\section{VIZSGÁLT ANYAG ÉS MUNKAMÓDSZEREK}

\section{Földtani háttér}

A lelőhely az Északi-Bakonyban, Bakonyjákó községtől nagyjából 3 km-re, Németbányától kb. $2 \mathrm{~km}$-re, míg az egykori Iharkút település határától néhány száz méterre (1. és 2. ábra) a Bakonyi Bauxitbánya Zrt. egykori külfejtéses bauxitbányájának Németbánya II. és III. lencsék területén található (ÖsI \& Mindszenthy 2009, Ösı et al. 2012). Ez a terület a mezozoikum során az Apuliai-mikrolemez északi részét képezte (Csontos \& VöRös 2004). Édesvízi és szárazföldi gerinces állatok maradványai egyaránt ismertté váltak (Ösı $e t$ al. 2012, MAKÁDI et al. 2014) a Csehbányai Formáció itt feltárt folyóvízi és ártéri üledékeiből, melyek a késő-kréta santoni időszakában rakódtak le (Ösı \& Mindszenthy 2009, Ösi et al. 2012, Botfalvai et al. 2016). A lelöhely feltételezett santoni korát pollen vizsgálat igazolta, mely utóbbi szerint az ősgerinces lelőhelyen feltárt üledékek lerakódása ezen időszak végére, az Oculopollis zaklinskaiae-Tetracolporopollenites (Brecolpites) globosus zónára tehető (BODOR \& BARANYI 2012). A lelőhelyen a legtöbb ősmaradvány az úgynevezett bázis-breccsából (Szál-6) került elő, kb. $99 \%$ a meghatározható leletekből (SzA Bó et al. 2016), mely egy zöldesszürke, durva agyagklasztos üledék, ahol többnyire koncentráltan, lencseszerü felhalmozódásokban fordulnak elö a többnyire izolált csontok, mint ahogy a jelen munkában leírt albanerpetontida csontok is. Szintén gyakoriak benne a növényi maradványok magvak és termések 
formájában, valamint kagyló-kőbelek is előfordulnak és gazdag csigafaunát is rejt magában (BODOR \& BARANYI 2012, SZENTESI 2012). A bázis-breccsára lepelszerüen homok-, homokkő, majd erre barna aleurolit települ (Ösı et al. 2012, BotFalvai et al. 2016). Töredékes kétéltủ csontok egyéb gerinces leletek mellett szintén előfordulnak egy sötétszürke színü, magas borostyántartalmú üledékben (Szál 7, 8, 10 és 11) is, valamint barna, vörös és hidromorf paleotalajokból is kerültek elő leletek. A barna aleurolit és egy világos színű agyagos réteg (Szál-7 alatt) viszonylag jó megtartású levél lenyomatokat rejt magában (BODOR \& BARANYI 2012).

1

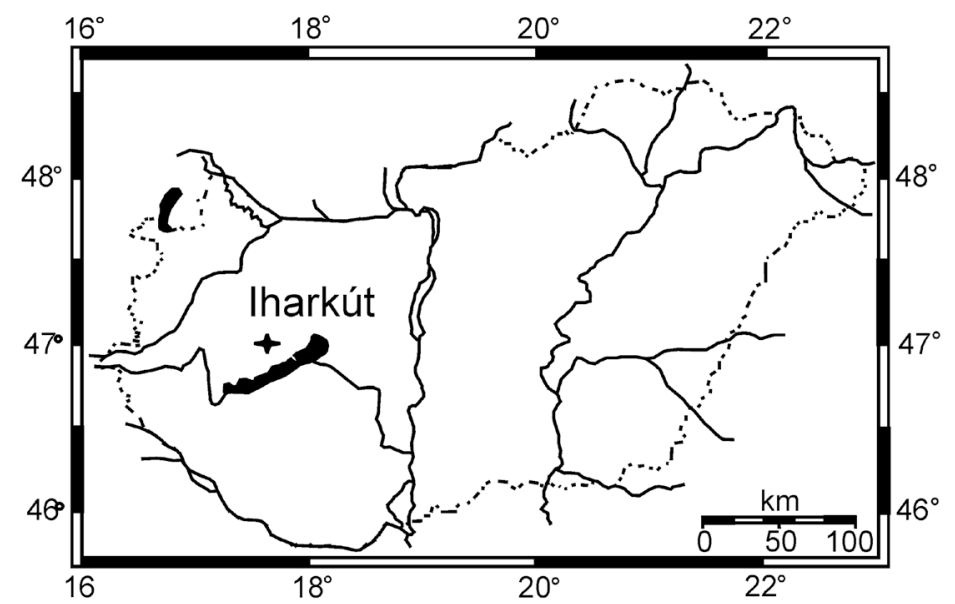

2

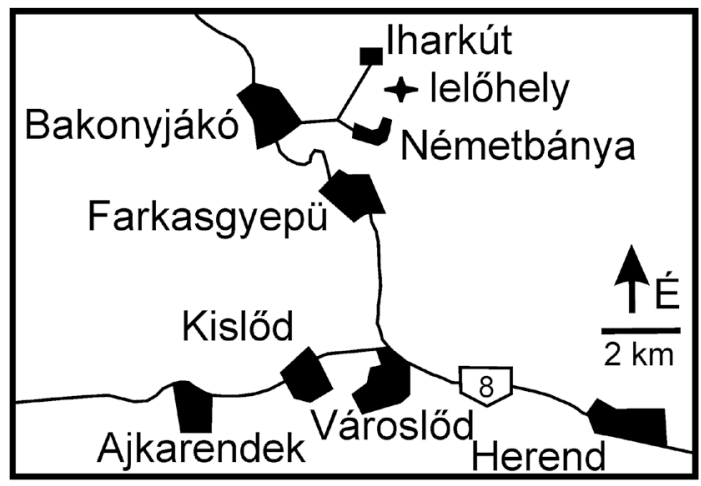

1-2. ábra. Az iharkúti késő-kréta (santoni) korú ősgerinces lelőhely földrajzi helyzete. 


\section{Vizsgált anyag}

VER 2015.134.13. frontale töredék, VER 2015.134.1. és VER 2015.134.2. bal dentalék, VER 2015.134.5. fogmaradványok (nem ábrázolt), VER 2015.134.8. bal dentale (nem ábrázolt).

A jelen tanulmányban vizsgált leletek a durva agyagklasztos bázisbreccsa (Szál-6) iszapolt üledékeiből kerültek elő annak makroszkópos és mikroszkópos vizsgálata során. A frontale-töredék ugyanezen üledékből, annak iszapolása (2.00, 1,00 és $0,32 \mathrm{~mm}$ szitákból álló szitasoron a lelöhely közelében fekvő bányatónál) és mikroszkópos (Nikon SMZ445 sztereomikroszkóp) válogatása során vált ismertté. Az ábrákhoz felhasznált fotók a MTM Növénytárában pásztázó elektronmikroszkóp (Hitachi S-2600N) segítségével történtek.

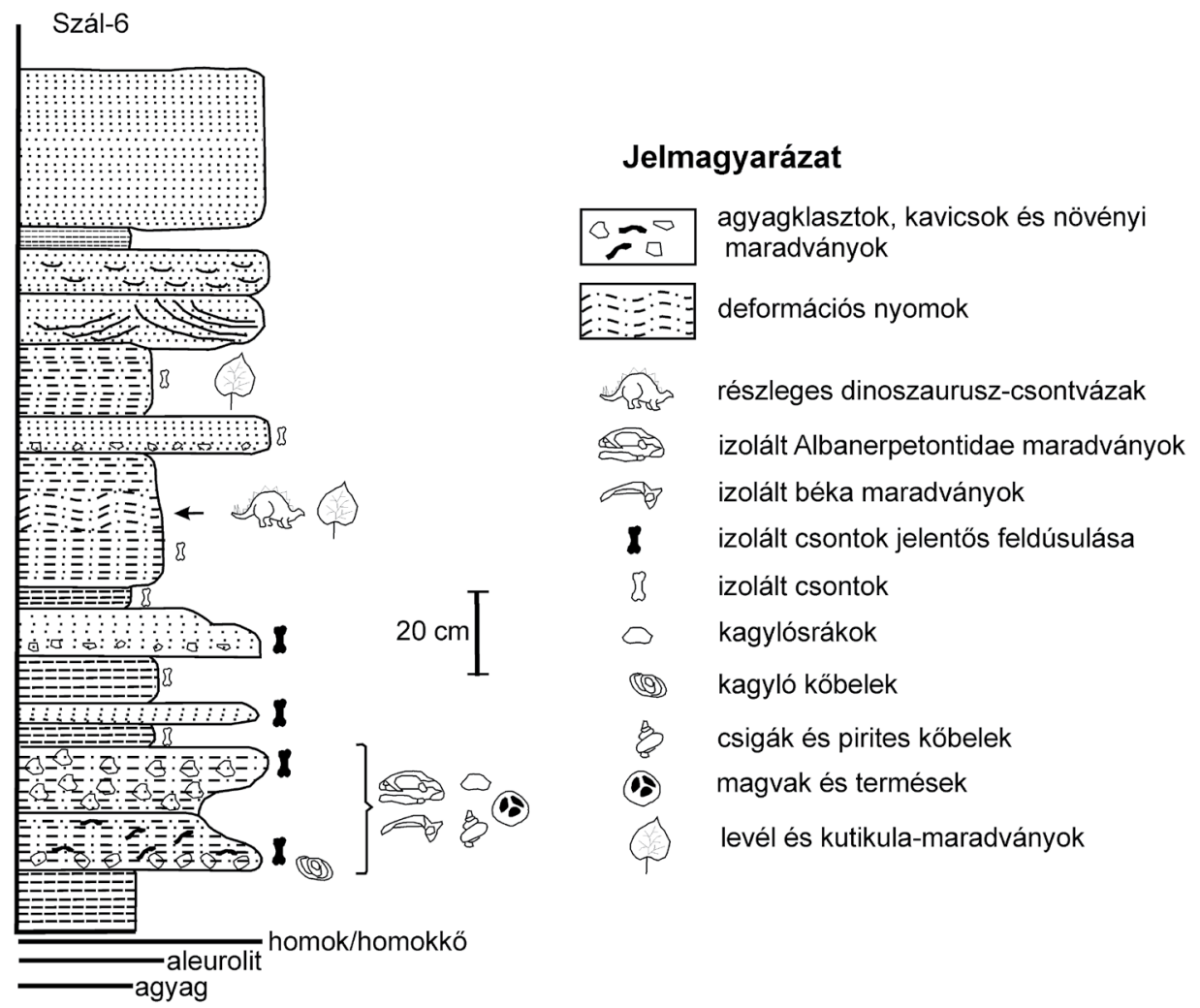

3. ábra. A Szál-6 gyűjtési terület elvi rétegoszlopa az iharkúti késő-kréta (santoni) korú ősgerinces lelőhelyen. (BOTFALVAi 2009 nyomán módosítva) 


\section{RENDSZERTANI RÉSZ \\ Classis Amphibia Gray, 1825 \\ Subclassis Lissamphibia Haeckel, 1866 \\ Ordo Allocaudata Fox \& Naylor, 1982 \\ Familia Albanerpetontidae Fox \& Naylor, 1982
Albanerpetontidae indet. A frontale-töredék
(VER 2015.134.13.)
(4. ábra) töredéknek jól látható egy méhsejtszerủ mintázat, mely gödröcskékből és bordák semmilyen diagnosztikus információt arról, hogy a családon belül mely taxonhoz}

Az iharkúti ősgerinces lelőhelyről eddig még nem került elő albanerpetontida frontale, ez az első töredék, mely ismertté vált. A dorsalis részén ennek a frontale hálózatából áll, melyek együtt alkotnak egy megnyúlt hatszög alakzatot. Ez a mintázat tipikus az Albanerpetontidae család képviselőinél (GARDNER 2000: Fig 6., Matsumoto \& Evans 2018: Fig. 10A). A gödröcskés felszínen több kisméretü foramen nyílik fel. A csont ventralis oldala teljesen sima, így nem nyújt tartozhat ez a töredék.

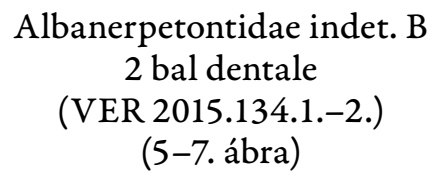

Sérülten is szokatlanul nagyméretünek számít ez a két bal dentale az ismert Albanerpetidae fajok között a maguk 9,8 mm (VER 2015.134.1.) és 9,3 mm (VER 2015.134.2.) hosszával. A sérült, nem teljes mértékben megőrződött példányokon a pleurodont fogaknak is csak a tövi részük őrződtek meg, ezért a csont magassága nem állapítható meg. Összehasonlítva az Iharkútról előkerült egyéb, fogakat is tartalmazó dentalék arányaival, e csontok magassága elérhette a $3 \mathrm{~mm}$-t is a poszterior részén. A részben megmaradt fogak alapján azok sürün, egymáshoz közel nőttek, és ventralis végüknél egy árokszerű képződmény látható. Lingualis nézetben a szubdentális perem lekerekített ventralis irányban, míg dorzális irányban élszerü, és poszterior irányban kiszélesedő. A Meckel-csatorna az anterior részen zárt és csak poszterior irányban nyílik fel (jórészt üledékkel van kitöltve), ahogy az a VER 2015.134.1. számú példányon megfigyelhető (5. ábra). A csontok anterior részén található szimfíziális villák (=furca symphysialis) erőteljesek és kihegyesedőek. A villák ágai közel hasonló méretűek. A szimfíziális csúcs (=apex symphysialis) habár csak részben maradt meg, de így is jól láthatóan 
túlnyúlik a szimfíziális villákon (5. ábra). Occlusalis nézetben a dentalék enyhén íveltek, a szubdentális perem viszonylag széles, a fogárok felé lejtve árkot képez a csont teljes hosszában. A dentale dorzális pereme egyik példányon sem ép, de a megmaradt részekből arra lehet következtetni, hogy vékony lehetett eredetileg. Labialis nézetben, amennyire az enyhén erodált felszínből következtetni lehet, a dentalék felszíne sima, néhány kisebb méretű foramen töri át a felszínét, és az intermandibuláris izmok tapadási helye is megfigyelhető alig észlehető alacsony gerincekként a csontokon. Ventralis nézetben a VER 2015.134.2. példányon megfigyelhető egy a szimfíziális villáktól kiinduló árok, mely poszterior irányban erősen elkeskenyedik, majd eltűnik (7. ábra).
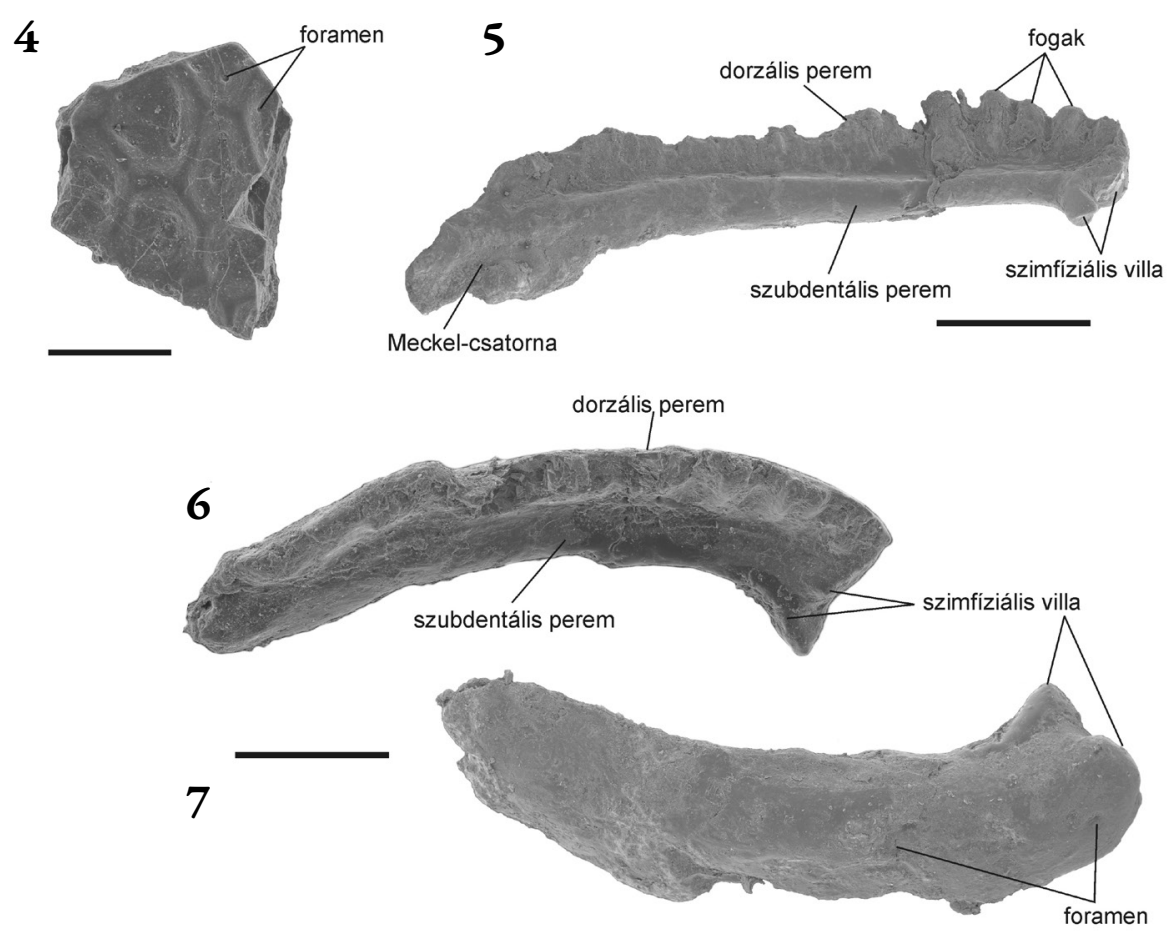

4-7. ábra. Albanerpetontidae indet. fosszíliák a késő-kréta (santoni) korú iharkúti lelőhelyről. 4 = Albanerpetontidae indet. A frontale töredék (VER 2015.134.13.), dorzális nézet, méretarány $0,5 \mathrm{~mm} .5$ = Albanerpetontidae B bal dentale (VER 2015.134.1.), lingualis nézet, méretarány $2 \mathrm{~mm} .6-7$ = Albanerpetontidae B bal dentale (VER 2015.134.2.), 6 = linguodorzális nézet és 7 = ventrolabiális nézet, méretarány $2 \mathrm{~mm}$. 
A dentalék ugyan sérültek, de egy az Albanerpetontidae családra jellemző autapomorf bélyeg, a szimfíziális villák megléte (GARDNER 2001) mindenképpen arra utal, hogy ezek a leletek ebbe a csoportba sorolhatóak. Ezt erősítik az egymás mellett szorosan elhelyezkedő pleurodont fogak jelenléte, a magas és vékony dorzális perem, az alacsony szubdentális perem, a csak poszterior irányban felnyíló Meckel-csatorna, a labialis felszínen megjelenő kisméretű foramenek és a ventrolabialisan megjelenő izomtapadási gerincek. A leletek közelebbi besorolása nem lehetséges, mert csak a frontale használható diagnosztikus elemként a genus vagy fajszintủ besoroláshoz az Albanerpetontidae családon belül.

$\mathrm{Az}$ iharkúti felső-kréta (santoni) ősgerinces lelőhelyről az ezt megelőzően leírt 6,4 mm hosszú, 8 fogat tartalmazó jobb dentale töredékkel (V 2008.29.1., SZENTESI $e t$ al. 2013, Fig. 3A) együtt a három nagyméretű dentale vált ismertté. Ide sorolható még egy 4 fogból álló, $1 \mathrm{~mm}$ széles állkapocs-töredék (V 2009.10.1., SZENTESI $e t$ al. 2013, Fig. $2 \mathrm{M}_{1}-\mathrm{M}_{2}$ ) is. Ezen csontok méretét összehasonlítva az itt Albanerpetontidae indet. A és B néven jelölt dentálékhoz hasonlóak, így egy taxonba sorolhatóak, melyek négyszer nagyobbak a gyakoribb, normálméretü fajnál. Ezek a csontok az eddig ismert legnagyobb dentálék az Albanerpetontidae családon belül. Habár egyelöre csak ez az óriási méretkülönbség utal rá, de minden bizonnyal legalább két, az Albanerpetontidae családba tartozó faj volt jelen az egykori élőhelyen.

\section{TÁRGYALÁS}

Tafonómiai megfigyelések

Az iharkúti késő-kréta (santoni) lelőhelyen a Csehbányai Formáció három üledéktípusából kerültek elő kétéltủ maradványok. A leggyakoribb a durva agyagklasztokból álló úgynevezett bázisbreccsa (Szál-6), melyből a jelen munkában bemutatott leletek is származnak, valamint a béka maradványok többsége is innen került elő. A másik egy sötétszürke színü, magas borostyántartalmú üledék (Szál 7, 8, 10 és 11), melyben az albanerpetontida maradványok vannak jelentős többségben a kétéltű leleteken belül, és a harmadik egy vörös színủ paleotalaj, melyből néhány töredékes béka végtagcsontot ismerünk (SzENTESI 2012). A lelőhelyről kizárólag izolált Albanerpetontidae leletek kerültek elő. A leletek a finomszemcsés pirittartalmuknak és valószínűleg kis részben a megmaradt szervesanyag-tartalmuknak köszönhetően fekete színűek. Az albanerpetontida csontok felszínén piritkiválás csak igen ritkán figyelhető meg. A felszínhez közeli, csapadéknak vagy rétegvíz-áramlásnak jobban kitett helyekről elökerült csontok világosbarnák vagy világosszürke színüek. Az albanerpetontida csontok mindegyike töredékes, sokszor csak kopott felszínü, és kizárólag koponyacsont- 
és állkapocstöredékeket ismerünk a lelőhelyről. Az albanerpetontida csontokon gyakran mikroszkopikus repedések figyelhetőek meg, melyek többnyire üledékkel, ritkábban kalcittal vannak kitöltve. Leggyakoribbak a dentale-töredékek, ritkábbak a premaxilla és maxilla leletek (SZENTESI 2012, SZENTESI et al. 2013), míg frontaléból csak az itt ábrázolt töredék ismert.

\section{Paleoökológiai és ősfoldrajzi következtetések}

A tafonómiai megfigyelések alapján az Albanerpetontidae csontmaradványok magasabb térszínekről, távolabbról kerülhettek a megtalálási helyükre, mert kizárólag izoláltan, és erősen töredezett formában kerültek napvilágra nem csak a nagyenergiájú vízből lerakódott bázisbreccsából (Szál-6), hanem a valószínűleg kisenergiájú vízben leülepedett (BоTFALVA et al. 2016) borostyános rétegekből (pl. Szál-7, 8 és 9) is. Az albanerpetontidákat a robosztus felépítésü koponyájuk, a specializált intermandibuláris valamint a koponya és a mandibula közötti ízesülés, és a módosult nyaki csigolya okán ásó életmódú állatként tartják nyilván, és újabb eredményként a kaméleonokéra emlékeztető táplálkozást is sikerült igazolni (Estes \& Hofstetter 1976, Fox \& Naylor 1982, McGowaN 1998, 2002; GARDNER 1999, 2001). A Magyarországról leírt (Csarnóta 2) pliocén korú Albanerpeton pannonicum esetében egy hosszú rétegsort követve bebizonyosodott, hogy ezen állatokat nem befolyásolta hátrányosan az egykori őskörnyezet erdősről füves pusztává válása az éghajlatváltozás következtében, mely VENCZEL \& GARDNER (2005) szerint a faj beásó életmódjának köszönhető. Árnyalja kissé a képet, hogy az újabb vizsgálatok szerint a pliocén végén a faj egyedszáma jelentős csökkenést szenvedhetett el, mely a Csarnóta 3 felsőpliocén lelőhely rétegsorában jól nyomon követhetö (SZENTESI et al. 2015). A pleisztocénben jelen ismereteink alapján egyáltalán nem találhatóak meg a rendbe sorolható leletek, ezért valószínűsíthető, hogy a fent említett éghajlatváltozás, ha nem is okozott sokkszerü hirtelen kihalást, azért hozzájárulhatott a faj lassú, fokozatos eltünéséhez. Ezen kívül hozzájárulhattak még a faj kihalásához egyéb tényezők is, mint a fauna változása: pl. új, ezen állatokra hatékonyabban vadászó ragadozó állatfajok megjelenése, vagy a hasonló ökológiai szerepet betöltő, ellenállóbb és/vagy nagyobb szaporodó képességű kétéltűek megjelenése. Az európai miocénben elterjedt $A$. inexpectatum maradványai egyaránt elöfordulnak ártéri, mocsári- és tavi üledékekben és karsztos kőzetek üregkitöltéseiben, habár az elöbbiekben sokkal gyakoribbak (GARDNER \& BöHME 2008, Table 12.2.; Sweetman \& Gardner 2013, Matsumoto \& Evans 2018). A mezozoikumi és paleocén előfordulások is főleg alföldi területekre (egykori vizes élőhelyekre) korlátozódnak, bár meg kell említeni, hogy a magasabban fekvő karsztos területek eróziónak voltak kitéve, ami oka lehet az ilyen típusú lelőhelyek hiányának. Az eddig megjelent szakirodalom alapján úgy tűnik, hogy az albanerpetontidák a stabilan nedves, árnyékos környezetet kedvelték. Egy nemrég megjelent 
tanulmány (SKUTSCHAS et al. 2021) szerint az Albanerpeton sensu lato genusba sorolható állatoknak bőrlégzése volt, amit a frontale erezettségének módja és a Sharpey-féle rostok hiánya támaszt alá. Ha ez igaz, akkor ezen állatoknak mindenképpen szükségük volt a bőrük folyamatosan nedvesen tartásához, vagyis nedves, párás környezethez. melynek közelében állandó víztest volt (GARDNER \& Böhme 2008, Table 12.2.; Sweetman \& Gardner 2013, Matsumoto \& EvANs 2018), mely ideális körülmények csapadékosabb éghajlatú időszakokban adottak lehettek egyes karsztos platókon is (GARDNER \& BöHME 2008).

Az eddig előkerült, az Albanerpetontidae családhoz sorolható 149 leletből összesen 4 példány ( 3 bal dentale és fogak dentale-töredéken) sorolható az óriásméretü albanerpetontidákhoz, melyek mind a bázisbreccsából (Szál-6) kerültek elő. A legkisebb egyedszám számítás szabályai szerint ezek a csontok legalább 3 egyedhez tartoztak, ami a normálméretủ albanerpetontidák 30 becsült egyedének mindössze a tizede. Ez utóbbiak maradványainak 69 \%-a került ki a bázisbreccsából (Szál-6), mely üledék képződése a nagyobb árvízi eseményekhez köthető (BOTFALVA I et al. 2016), vagyis az elöntéssel ritkábban érintett területről is gyüjthetett be maradványokat.

A lelőhelyről a Szál-6, és Szál-7 és 8 rétegekből előkerült szárazfa-termesz koprolitok (Microcarpolithus hexagonalis ichnotaxon; VANGEROW 1954) jelenléte (VASILE et al. 2013, 2014) is utalhat arra, hogy árvizekkel ritkábban érintett részek is lehettek az egykori területen, ugyanis ezek az állatok a szervezetük számára szükséges nedvességet az általuk fogyasztott fából nyerik, így nincs szükségük állandó egyéb nedvességre. A termeszvár megőrződése szempontjából sem előnyös a vizes környezet (NALEPA 2015). Ez csak látszólag ellentmondás a feltételezett bőrlégzéshez szükséges nedves környezettel, ugyanis a nagyobb árvizek után a magasabban fekvő területeken is számos időszakos tavacska, tocsogó is fennmarad, melyek elegendő nedvességet tudnak biztosítani az azt igénylő állatoknak. Ezen ismeretek birtokában valószínűsíthető, hogy az iharkúti albanerpetontidák az egykori folyó szintjénél magasabb térszínen élhettek és csak a nagyobb áradások során mosódhattak maradványaik a bázisbreccsa (pl. Szál-6) néven leírt üledékekbe. Az alacsonyabb energiájú vizekben lerakódott borostyán-tartalmú üledékekbe (pl. Szál-7 és 8) is magasabb térszínről kerülhettek a maradványok, melyet töredezettségük és kopottságuk is jelez, mely szintén arra utal, hogy nem e mélyebb térszínen képződött üledékek őskörnyezete lehetett az élőhelyük. Az alacsony leletszám okán nem jelenthetjük ki azt, hogy az óriásméretủ csak ott élt együtt a normálméretủ albanerpetontidákkal, ahonnan a bázisbreccsába mosódhattak a maradványai. 


\section{ÖSSZEGZÉS}

Az itt leírt frontale töredék az első ilyen típusú csont, mely ismertté vált az iharkúti felső-kréta ősgerinces lelőhelyről, mely reményt ad arra, hogy idővel jobb megtartású lelet is előkerülhet, mely segítségével esetleg az itt fellelt albanerpetontida leletek taxonómiai besorolásában is történhet elörelépés.

$\mathrm{Az}$ újabban előkerült nagyméretű albanerpetontida dentalék megerősítik, hogy az egykori élőhelyen legalább két, az Albanerpetontidae családba sorolható faj élt, melyből az egyik az eddig ismert legnagyobb méretủ faj volt.

$\mathrm{Az}$ óriásméretű albanerpetontidák lényegesen ritkábbak lehettek, mint a normálméretű taxonba tartozók.

A tafonómiai megfigyeléseket, valamint a szakirodalmat figyelembe véve az iharkúti albanerpetontidák a folyó szintjénél magasabb térszínen, de nedves és növényzettel borított környezetben élhettek.

Köszönetnyilvánitás - A szerző hálával tartozik az iharkúti rendszeres ásatáson résztvevő kollégáinak és Dr. Ösi Attilának (ELTE TTK FFI Öslénytani Tanszék), hogy rendelkezésre bocsátotta ezt az anyagot és Dr. Buczkó Krisztinának (Magyar Természettudományi Múzeum, Növénytár) a kiváló minőségű elektronmikroszkópos felvételek elkészítésében nyújtott segítségéért. Külön köszönet illeti Dr. Venczel Mártont (Körösvidék Múzeum, Nagyvárad, Románia) e munka alapos bírálatáért és a hasznos tanácsaiért.

\section{HIVATKOZÁSOK}

Bodor E. R. \& BARANyi V. 2012: Palynomorphs of the Normapolles group and related plant mesofossils from the Iharkút vertebrate site, Bakony Mountains Hungary). - Central European Geology 55(3): 259-292.

Botfalvai G. 2009: Az iharkúti késő-kréta kontinentális gerinces lelőhely tafonómiai vizsgálata.-Diplomamunka, ELTE TTK Öslénytani Tanszék, Budapest: pp. 1-106.

Botfalvai G., HaAs J., Bodor E. R., Mindszenty A. \& Ősi A. 2016: Facies architecture and palaeoenvironmental implications of the upper Cretaceous (Santonian) Csehbánya formation at the Iharkút vertebrate locality (Bakony Mountains, Northwestern Hungary). Palaeogeography, Palaeoclimatology, Palaeoecology 441: 659-678.

Csontos L. \& VöRös A. 2004: Mesozoic plate tectonic reconstruction of the Carpathian region. Palaeogeography, Palaeoclimatology, Palaeoecology 210: 1-56.

Delfino M. \& Sala B. 2007: Late Pliocene Albanerpetontidae (Lissamphibia) from Italy. Journal of Vertebrate Paleontology 27: 716-719. 
Estes R. \& Hofstetter R. 1976: Les Urodèles du Miocène de La Grive-Saint-Alban (Isère, France). - Bulletin du Muséum National d'Histoire Naturelle, 3e Série, no. 398, Sciences de la Terre 57: 297-343.

Evans S. E. \& Milner A. R. 1994: Middle Jurassic microvertebrate assemblages from the British Isles. - In: FrASER N. C. \& SUES H.-D. (eds.): In the shadow of the dinosaurs: Early Mesozoic tetrapods - Cambridge University Press, New York, New York. pp. 303-321.

Evans S. E. \& Waldman M. 1996: Small reptiles and amphibians from the Middle Jurassic of Skye, Scotland. In: Morales M. (ed.): The continental Jurassic, Museum of Northern Arizona Bulletin 60: 219-226.

Fox R. C. \& NAYLOR B. G. 1982: A reconsideration of the relationships of the fossil amphibian Albanerpeton. - Canadian Journal of Earth Sciences 19: 118-128.

GARDNER J. D. 1999: Redescription of the geologically youngest albanerpetontid (?Lissamphibia): Albanerpeton inexpectatum Estes and Hofstetter, 1976, from the Miocene of France. Annales de Paléontologie 85(1): 57-84.

Gardner J. D. 2001: Monophyly and affinities of albanerpetontid amphibians Temnospondyli; Lissamphibia). - Zoological Journal of the Linnean Society 131: 309-352.

Gardner J. D. \& Böhme M. 2008: Review of the Albanerpetontidae (Lissamphibia), with comments on the paleoecological preferences of European Tertiary albanerpetontids. In: SANKEY J. T.\& BASzio S. (eds.): Vertebrate micofossil assemblages: their role in paleoecology and paleobiogeography - Indiana University Press, Bloomington, Indiana, pp. 178-218.

MAKÁDI L., BOTFALVAI G. \& Ősi A.2006: Késő-kréta kontinentális gerinces fauna a Bakonyból I.: halak, kétéltűek, teknősök, gyíkok - Földtani Közlöny 136(4): 487-502.

MAKádi L., Rabi M., Csengödi D., Szentesi Z. \& Ösi A. 2014: Bakonyi dinoszauruszok és más hazai mezozoós gerincesek a Magyar Természettudományi Múzeum gyűjteményében az elmúlt évek világhírủ felfedezései. - Annales Historica-Naturales Musei Nationales Hungarici 106: 71-116.

Matsumoto R. \& Evans S. E. 2018: The first record of albanerpetontid amphibians (Amhibia: Albanerpetontidae) from East Asia. - PlosOne 13(1): e0189767

McGowan G. J. 1998: Frontals as diagnostic indicators in fossil albanerpetontid amphibians. Bulletin of the National Science Museum Series C (Geology and Paleontology) 24: 185-194.

MCGowan G. J. 2002: Albanerpetontid amphibians from the Lower Cretaceous of Spain and Italy: a description and reconsideration of their systematics. - Zoological Journal of the Linnean Society 135: 1-32.

McGowan G. J. \& Evans S. E. 1995: Albanerpetontid amphibians from the Cretaceous of Spain. Nature 373: 143-145.

NALEPA C. A. 2015: Origin of termite eusociality: trophallaxis integrates the social, nutritional, and microbial environments. - Ecological Entomology 40(4): 323-335.

Ösi A., Makádi L., Rabi M., Szentesi Z., Botfalvai G. \& Gulyás P. 2012: The Late Cretaceous continental vertebrate fauna from Iharkút, western Hungary: a review. - In: Godefroit P. (ed.): Bernissart Dinosaurs and Early Cretaceous Terrestrial Ecosystems Indiana University Press, Bloomington pp. 533-568. 
Ösi A. \& Mindszentriy A. 2009: Iharkút, Dinosaur-bearing alluvial complex of the Csehbánya Formation. - In: BABINszky E. (ed.): Cretaceous Sediments of the Transdanubian Range. Field Guide of the Geological Excursion Organized by the Sedimentological Subcommission of the Hungarian Academy of Sciences and the Hungarian Geological Society. pp. 51-63.

SEIFFERT J. 1969: Urodelen-Atlas aus dem obersten Bajocien von SE-Aveyron Südfrankreich). Paläontologische Zeitschrift 43: 32-36.

Skutschas P. P., Kolchanov V. V. \& GardneR J. D. 2021: Microanatomy and frontal bones of two species of Albanerpeton sensu lato (Lissamphibia, Albanerpetontidae) from the Upper Cretaceous Oldman Formation in southeastern Alberta, Canada. - Historical Biology, doi: https://doi.org/10.1080/08912963.2021.1881084

SWeEtman S. C. \& GARDNER J. D. 2013: A new albanerpetontid amphibian from the Barremian (Early Cretaceous) Wessex Formation of the Isle of Wight, southern England. - Acta Paleontologica Polonica 58(2): 295-324.

Sza Bó M., Gulyás P. \& Ösı A. 2016: Late Cretaceous (Santonian) Atractosteus (Actinopterygii, Lepisosteidae) remains from Hungary (Iharkút, Bakony Mountains). - Cretaceous Research 60: 239-252.

Szentesi Z. 2006a: Késő-kréta kétéltűek a Csehbányai Formációból (Iharkút, Bakony). - In: PÁlfy J., Makádi L. \& Ozsvárt P. (eds.): 9. Magyar Öslénytani Vándorgyülés, Program, Elöadáskivonatok, Kirándulásvezetö, 2006 Ajka, május 18-20.,pp. 20-21.

Szentesi Z. 2006b: Late Cretaceous amphibians from the Csehbánya Formation of Hungary (Iharkút, Bakony Mountains). In: Pazonyi P. (ed.): Hantkeniána 5, Extended Abstracts, Abstracts, and Excursion Guidebook, $4^{\text {th }}$ Annual Meeting of the European Association of Vertebrate Paleontologists, Budapest, Hungary, p. 108.

SZEnTESI Z. 2012: Az iharkúti késő-kréta kétéltű fauna vizsgálata taxonómiai, funkcionális anatómiai, paleoökológiai és paleobiogeográfiai szempontból. - Ph.D. disszertáció, Budapest, ELTE TTK FFI, Öslénytani Tanszék, pp. 1-139.

Szentesi Z., Gardner J. D. \& Venczel M. 2013: Albanerpetontid amphibians from the Late Cretaceous (Santonian) of Iharkút, Hungary, with remarks on regional differences in Late Cretaceous Laurasian amphibian assemblages1, 2. - Canadian Journal of Earth Sciences 50: $268-281$.

Szentesi Z., Makádi L., Rabi M., Botfalvai G. \& Ösi A. 2006: Felső-kréta gerinces a Csehbányai Formációból (Iharkút). - Bányászati és Kohászati Lapok, Bányászat 139(6): 45-49.

Szentesi Z., Pazonyi P. \& Mészáros L. 2015: Albanerpetontidae from the late Pliocene (MN16A) Csarnóta 3 locality (Villány Hills, South Hungary) in the collection of the Hungarian Natural History Museum. - Fragmenta Paleontologica Hungarica 32: 49-66.

Szentesi Z. \& VenCzel M. 2010: An advanced anuran from the Late Cretaceous (Santonian) of Hungary. - Neues Jahrbuch für Geologie und Paläontologie -Abhandlungen 256: 291-302.

Szentesi Z. \& VenCZeL M. 2012: A new discoglossid frog from the Late Cretaceous (Santonian) of Hungary. - Cretaceous Research 34: 327-333.

VANGEROW E. F. 1954: Megasporen und andere pflanzlich Mikrofossilien aus den Aachen Kreide. Palaeonthographica B 96: 24-38. 
Vasile Ş., Bodor E. R., Csiki-Sava Z. \& Szentesi Z. 2013: Isopterian trace fossils from the Late Cretaceous of Central-Eastern Europe. - In: TAB ĂRĂ D. (ed.): Abstract Book of Ninth Romanian Symposium of Paleontology, Iaşi 25-26 October 2013, Iaşi, Románia, pp. 88-89.

Vasile Ş., Bodor E. R., Csiki-Sava Z. \& Szentesi Z. 2014: "Neighbour, I think we have termites!"-Isopterian feeding traces from the Upper Cretaceous of Hungary and Romania. In: Popa L. O., Adam C., Chişamera G., Iorgu E., Murariu D. \& Popa O. P. (eds.): Book of Abstracts of International Zooligical Congress of "Grigore Antipa" Museum, 19-22 November 2014, Bucharest, Romania, p 71.

VENCZEL M. \& GARDNER J.D. 2005: The geologically youngest albanerpetontid amphibian from the Lower Pliocene of Hungary. - Palaeontology 48: 1273-1300.

\title{
New Albanerpetontid remains (Allocaudata: Albanerpetontidae) from the Late Cretaceous terrestrial paleovertebrate locality of Iharkút
}

\author{
ZOLTÁN SZENTESI \\ Hungarian Natural History Museum, Department of Paleontology and Geology, \\ H-1088 Budapest, Pf. 137., Hungary \\ E-mail:szentesi.zoltan@nhmus.hu
}

\begin{abstract}
Isolated and fragmentary fossils of albanerpetontid amphibians (Albanerpetontidae: Allocaudata) are frequent in the Iharkutian Late Cretaceous (Santonian) paleovertebrate site but these fossils are classifiable only on family level because the taxonomically diagnostic frontal bone is unknown. Despite these, the remains can be well separated into two groups based on their size (normal and giant) which suggest that at least two unidentified species are present in this fossil material. Two left dental specimens confirm this assumption and also suggest that the giant sized albanerpetontids were not uncommon in the Santonian of this former area. With 7 figures and 1 table.
\end{abstract}

Key words - Albanerpetontidae, Cretaceous, Iharkút, paleoecology, paleoenvironment 


\section{FIGURE AND TABLE LEGENDS}

Table 1. Albanerpetontidae fossils from the Late Cretaceous (Santonian) Iharkutian paleovertebrate site.

Figures 1-2. Geographical position of the Iharkutian Late Cretaceous (Santonian) paleovertebrate site.

Figure 3. Conceptual geological column of the Szál-6 fossil collecting area at the Iharkutian Late Cretaceous (Santonian) paleovertebrate site (modified after Bot FALVAI 2009). Translation of Hungarian terminology (in alphabetical order): agyag = clay; agyagklasztok, kavicsok és növényi maradványok = clay clasts, pebbles and plant fossils; aleurolit = silt; csigák és pirites kőbelek = gastropods and pyretes casings; deformációs nyomok = traces of deformations; homok/homokkő = sand/sandstone; izolált Albanerpetontidae maradványok $=$ isolated Albanerpetontidae remains; izolált béka maradványok = isolated frog remains; izolált csontok = isolated bones; izolált csontok jelentős feldúsulása = significant enrichment of isolated bones; kagyló kőbelek = clam fossil casings; kagylósrákok = ostracods; levél és kutikulamaradványok = leafs and cuticle remains; magvak és termések = seeds and fruits; részleges dinoszaurusz-csontvázak = partial dinosaur skeletons.

Figures 4-7. Albanerpetontidae indet. fossils from the Late Cretaceous (Santonian) Iharkutian vertebrate fossil site. $4=$ Albanerpetontidae indet. A frontal fragment (VER 2015.134.13.), in dorsal view, scale $0,5 \mathrm{~mm} .5$ = Albanerpetontidae B left dental (VER 2015.134.1.), in lingual view, scale $2 \mathrm{~mm} .6-7=$ Albanerpetontidae B left dental (VER 2015.134.2.), 6 = in linguodorsal view and $7=$ in ventrolabial view, scale $2 \mathrm{~mm}$. 